\title{
TEORI-TEORI YANG MEMBERI DASAR HUKUM BAGI \\ KEKUASAAN NEGARA
}

\author{
Maharani Shayuri Sato \\ Email: shayurisato@gmail.com \\ No BP: 2110003600017 \\ Universitas Ekasakti
}

\section{A. PENDAHULUAN}

Seiring dengan perkembangan zaman dan ilmu pengetahuan kehidupan bernegara mengalami banyak perubahan. Konsep negara mulai mengalami pergeseran yang pada awalnya negara merupakan negara yang berdasarkan pada kekuasan beralih pada konsep negara yang mendasarkan atas hukum (rechtstaat). Ajaran negara berdasarkan atas hukum mengandung pengertian bahwa hukum adalah supreme dan kewajiban bagi setiap penyelenggara negara atau pemerintah untuk tunduk pada hukum. Atas dasar pernyataan diatas maka tidak boleh ada kekuasaan yang sewenang-wenang (arbitrary power) atau penyalahgunaan kekuasaan (misuse of power) baik pada negara berbentuk kerajaan maupun republik. Secara maknawi, tunduk pada hukum mengandung pengertian pembatasan kekuasaan seperti halnya ajaran pemisahan dan pembagian kekuasaan. Oleh sebab itu, negara berlandaskan hukum memuat unsur pemisahan atau pembagian kekuasaan.

Masalah tujuan negara merupakan suatu hal yang amat penting bagi suatu negara. Berdasarkan tujuan negara ini, maka akan ditetapkan apa sebenarnya tugas dari organisasi negara (fungsi negara) yang berkaitan erat dengan lembaga-lembaga pendukungnya. Demikian pentingnya tujuan suatu negara, sehingga beberapa negara mencantumkan tujuan negara dalam pembukaan Undang-Undang Dasar 1945 yang merupakan Undang-Undang Dasar Negara Republik Indonesia. Setiap negara tentu mempunyai tujuan yang berbeda-beda, sesuai dengan latar belakang sejarah, budaya dan pandangan hidup dari masing-masing negara. Hal ini menimbulkan pula perbedaan dalam menentukan cara mencapai tujuan negaranya, termasuk cara menentukan sistem hukumnya. 
Dalam teori ilmu negara kita mengenal beberapa teori tentang tujuan Negara. Pertama, teori yang dikaitkan dengan tujuan akhir manusia yaitu kebahagiaan hidup di akhirat, sehingga mempengaruhi pula dalam melaksanakan kehidupan di dunia. Teori ini bersifat teokratis, dimana kegiatan kenegaraan juga dipengaruhi oleh nilai-nilai keagamaan. Kedua, teori yang bertujuan untuk mendapatkan dan mempertahankan kekuasaan sehingga menimbulkan negara kekuasaan (machstaat). Ketiga, teori yang bertujuan untuk mencari kemakmuran, yaitu teori kemakmuran negara, teori kemakmuran individu dan teori kemakmuran rakyat. Tujuan teori kemakmuran ini, menimbulkan beberapa teori tentang tipe negara hukum, yaitu tipe negara hukum liberal, tipe negara hukum formal dan tipe negara hukum material. Pada dasarnya timbulnya teori tipe negara hukum ini khususnya di negaranegara Eropa kontinental, merupakan suatu reaksi atau penolakan atas adanya kekuasaan yang otoriter dalam negara, yang disebabkan oleh adanya tujuan mencari kekuasaan dan tujuan mencari kemakmuran negara/penguasa. Oleh karena itu, dalam tipe negara hukum ditentukan syarat-syarat tertentu yang tidak boleh dilanggar oleh penguasa sebagai usaha untuk membatasi kekuasaan penguasa dalam negara. Sedangkan latar belakang timbulnya negara hukum di negara-negara anglosaxon, adalah mengutamakan perlindungan hak asasi manusia, sebagai wujud perlindungan hak dan kebebasan individu.

Tujuan Negara Republik Indonesia tercantum dalam alinea 4 pembukaan UndangUndang Dasar 1945. Sedangkan rumusan tentang Negara hukum Indonesia dapat kita jumpai pada penjelasan Undang-Undang Dasar 1945 (sebelum amandamen) dan pasal 1 ayat 3 batang tubuh Undang-Undang Dasar 1945 (hasil amandemen). Berdasarkan uraian diatas, maka penulis dapat merumuskan masalah yaitu: teori-teori apa saja yang mendasari hokum bagi kekuasaan Negara? 


\section{B. PEMBAHASAN}

Teori-teori yang memberi dasar hukum bagi kekuasaan negara dalam garis besarnya dapat dibagi atas tiga kelompok besar,yaitu:

1. Teori Teokrasi (Theocratische Theorie).

Sejarah Teori Teokrasi itu muncul dari para ahli filosof pada masa lampau di Eropa yang menganggap dan mengajarkan bahwa Hukum itu berasal dari Tuhan Yang Maha Esa . Maka manusia diperintahkan Tuhan harus tunduk pada Hukum Teokrasi dalam bahasa yunani yaitu:”Theokrate”(Tuhan) dan “Kratein”(memrihtah) Dalam artian Teori Teokraai adalah bentuk pemerintahan dimana prinsip ilaho memegang peran.

Teori ketuhanan lahir sebagai Resultante-resultante kontroversial dari kekuasaa politik dalam abad pertengahan.Kaum mobarchomach yaitu mereka berpendapat bahwa raja yang berkuasa secara tiranik dapat diturunkan dari mahkotanya, bahkan dapat dibunuh, menganggap sumber kekuasaan adalah rakyat, Sedangkan raja-raja pada waktu itu menganggap sumber kekuasaan mereka diperoleh dari tuhan.Negara dibentuk oleh tuhan dan Pemimpin-pemimpin negara ditunjuk oleh tuhan.Raja dan Pemimpin-pemimpin negara hanya bertanggung jawab pada tuhan dan tidak kepada siapapun.

Teori Teokrasi dibagi atas dua bagian, yaitu :

Teori Teokrasi Langsung(primitif).

Istilah langsung menunjukkan bahwa yang berkuasa di dalam negara itu adalah langsung Tuhan. Adanya negara di dunia ini adalah atas kehendak Tuhan, dan yang memerintah adalah Tuhan. Apakah negara semacam ini pernah ada ? Persoalan ini sebenarnya berpusat pada kepercayaan rakyat terhadap rajanya yang disebut sebagai Tuhan. Rakyat lain yang tidak berkeyakinan seperti itu, tentu 
akan memberi penilaian yang lain pula terhadap raja yang dianggapnya sebagai Tuhan.

Teori Teokrasi Tidak Langsung(modern).

Menurut penganut teori, bukan Tuhan sendiri yang memerintah suatu negara, melainkan seorang Raja atas nama Tuhan. Raja memerintah atas kehendak Tuhan sebagai karunia.Pada Teori Teokrasi modern ini diusahakan agar kekuasaan raja mendapatkan sifatnya yang suci (dalam arti "Ketuhanan"), sehingga pelanggaran terhadap kekuasaan raja merupakan pelanggaran terhadap Tuhan.

2. Teori Kekuasaan (Machtatheorie)

Asal muka kekuasaan karena Adanya keunggukan Kekuatan dari pada orang yang satu terhadap lainnya.Kekuasaan Merupakan Kewenangan yang bisa didapatkan oleh seseorang atau kelompok untuk menjalankan kwenangan tersebut sesuai dengan kewenangan yang telah diberikan.

Menurut Harold D.Iaswell Teori Teokrasi ini merupakan Kemampuan pelaku untuk memengaruhi tingkah laku pelaku lain sedemikian rupa, sehingga tingkah laku pelaku terakhir menjadi sesuai dengan keingan dari pelaku yang mempunyai kekuasaan. Teori ini mengatakan bahwa Manusia itu menbentuk negara dengan mengadakan perjanjian dengan masyarakat.

Menurut Teori ini kekuatan yang berkuasa adalah yang paling kuat(jasmani/fisik), kemudian apabila keluarga tersebut berkembang menjadi sebuah Masyarakat dan Negara, maka kekuasaan tetap berkuasa didalam Masyarakat dan Negara. Teori Kekuasaan dibagi atas dua bagian yaitu:

a. Kekuasaan Jasmaniah (Fisik)

Tokoh dari ajaran ini adalah Thomas Hobbes dan Machiavelli. 
Thomas Hobbes dalam bukunya yang berjudul Leviathan, ia membedakan dua macam status manusia yaitu :

1. Status Naturalis

Kedudukan manusia waktu masih belum ada negara. Dalam status naturalis, negara masih belum terbentuk, masyarakatnya masih kacau. Dalam keadaan ini perselisihan mudah timbul karena sifat manusia dalam keadaan tidak tertib itu merupakan srigala bagi yang lain (Homo Homini Lupus), kalau keadaan ini dibiarkan teruis menerus akan timbul perang semesta (Bellum Omnium Contra Omnes). Jadi syarat yang penting menurut Thomas Hobbes menjadi seorang raja adalah orang yang kuat fisiknya, yang melebihi lainnya agar dapat mengatasi segala kekacauan yang timbul dalam masyarakat

\section{Status Civilis}

Yaitu kedudukan manusia setelah ada negara sebagai warga negara.

Machiavelli, dalam bukunya yang berjudul Il Principle, ia mengajarkan kepada rajaraja bagaimana cara untuk memerintah sebaik-baiknya. Menurut Machiavelli, seorang raja harus kuat dan tahu cara mengatasi segala kekacauan yang dihadapi negara, ia dapat menggunakan segala alat untuk menguntungkannya.

\section{b. Teori Kekuasaan Ekonomi.}

Tokoh dari teori ini adalah Karl Marx. Marx menganggap bahwa negara itu merupakan alat kekuasaan bagi segolongan manusia di dalam masyarakat untuk menindas golongan lainnya guna mencapai tujuannya. Sebagai dasar dari ajaran Marx adalah pertentangan kelas dalam masyarakat dalam dua kelas, yaitu kaum yang ekonominya kuat dan kaum yang ekonomi lemah. Pertentangan antara dua 
kelas itu ditujukan untuk merebut kekuasaan negara sebab negara adalah alat kekuasaan. Yang penting dalam teori kekuasaan ekonomi dari Karl Marx adalah sandarannya yang disebut historische materialisme yaitu bahwa sejarah kehidupan manusia itu dipengaruhi oleh kebendaan.

\section{Teori Yuridis}

Teori yuridis merupakan pertimbangan atau alasan yang menggambarkan bahwa peraturan yang dibentuk untuk mengatasi permasalahan hukum atau mengisi kekosongan hukum dengan mempertimbangkan aturan yang telah ada, yang akan diubah, atau yang akan dicabut guna menjamin kepastian hukum dan rasa keadilan masyarakat. Landasan yuridis menyangkut persoalan hukum yang berkaitan dengan substansi atau materi yang diatur sehingga perlu dibentuk Peraturan PerundangUndangan yang baru. Beberapa persoalan hukum itu, antara lain, peraturan yang sudah ketinggalan, peraturan yang tidak harmonis atau tumpang tindih, jenis peraturan yang lebih rendah dari Undang-Undang sehingga daya berlakunya lemah, peraturannya sudah ada tetapi tidak memadai, atau peraturannya memang sama sekali belum ada. Teori ini dibagikan dalam 3 golongan yaitu:

a. Teori Patriarchaal.

Teori patriachaal ini berdasarkan hukum keluarga jaman dahulu, ketika masyarakat masih sangat sederhana dan pada waktu negara belum ada, maka masyarakat hidup dalam kesatuan-kesatuan keluarga besar yang dipimpin oleh seorang kepala keluarga. Seorang kepala keluarga merupakan primus interparis, artinya seorang yang pertama di antara yang sama, karena sifat-sifatnya yang lebih itu, maka ia menjadi orang yang dipuja-puja.

b. Teori Patriamonal 
Patriamonal berasal dari istilah patrimonium yang artinya adalah hak milik. Oleh karena raja mempunyai hak milik terhadap daerahnya maka semua penduduk di daerahnya itu harus tundauk kepadanya.

c. Teori Perjanjian.

Menurut Thomas Hobbes manusia itu selalu hidup dalam ketakutan, yaitu takut akan diserang oleh manusia lain yang lebih kuat. Karena itu lalu diadakan perjanjian masyarakat dan dalam perjanjian itu raja tidak diikutsertakan. Jadi perjanjian itu diadakan antara rakyat dengan rakyat sendiri. Setelah diadakan perjanjian masyarakat, dimana individu-individu menyerahkan haknya (hal-hak asasinya) kepada suatu kolektivitas yaitu suatu kesatuan dari individu-individu yang diperolehnya melalui pactum uniones, maka di sini kolektivitas itu menyerahkan hak-haknya atau kekuasaannya kepada raja dalam pactum subyektiones tanpa syarat apapun juga. Raja sama sekali ada di luar perjanjian, dan oleh karenanya raja mempunyai kekuasaan yang mutlak setelah hak-hak rakyat diserahkan kepadanya. Sistem negara seperti ini disebut Monarchie Absoluut.

Menurut John Locke antara raja dengan rakyat diadakan perjanjian dan karena perjanjian itu raja berkuasa untuk melindungi hak-hak rakyat. Akibat adanya perjanjian antara rakyat dengan raja maka timbul Monarchi Constitusional, kekuasaan raja dibatasi oleh konstitusi. Dalam perjanjian masyarakat tersebut terdapat dua macam pactum yang disebut sebagai :

1. Pactum Uniones, yaitu perjanjian untuk membentuk suatu kesatuan antara individu-individu, dan

2. Pactum Subyektiones, yaitu perjanjian penyerahan kekuasaan antara rakyat dengan raja. 
Paham Rousseau adalah kebalikan daripada Hobbes. Ajaran Rousseau adalah kedaulatan rakyat dan rakyat tidak pernah menyerahkan kepada raja, bahkan kalau ada raja yang memerintah, raja itu hanya sebagai mandataris dari rakyat.

\section{PENUTUP}

Masalah tujuan negara merupakan suatu hal yang amat penting bagi suatu negara. Berdasarkan tujuan negara ini, maka akan ditetapkan apa sebenarnya tugas dari organisasi negara yang berkaitan erat dengan lembaga-lembaga pendukungnya. Demikian pentingnya tujuan suatu negara, sehingga beberapa negara mencantumkan tujuan negara dalam pembukaan UUD 1945. Setiap negara tentu mempunyai tujuan yang berbeda-beda, sesuai dengan latar belakang sejarah, budaya dan pandangan hidup dari masing-masing negara. Hal ini menimbulkan pula perbedaan dalam menentukan cara mencapai tujuan negaranya, termasuk cara menentukan sistem hukumnya.

Dalam teori ilmu Negara ada beberapa teori tentang tujuan Negara. Pertama, teori yang dikaitkan dengan tujuan akhir manusia yaitu kebahagiaan akhirat, sehingga mempengaruhi pula dalam melaksanakan kehidupan di dunia. Teori ini bersifat teokratis, dimana kegiatan kenegaraan dipengaruhi oleh nilai keagamaan. Kedua, teori yang bertujuan untuk mempertahankan kekuasaan sehingga menimbulkan negara kekuasaan. Ketiga, teori yang bertujuan untuk mencari kemakmuran, yaitu teori kemakmuran negara, teori kemakmuran individu dan teori kemakmuran rakyat. 


\section{DAFTAR PUSTAKA}

Darmini Roza dan Laurensius Arliman S, Peran Pemerintah Daerah Di Dalam Melindungi Hak Anak Di Indonesia, Masalah-Masalah Hukum, Volume 47, Nomor 1, 2018. https://doi.org/10.14710/mmh.47.1.2018.10-21

Laurensius Arliman S, Peranan Metodologi Penelitian Hukum di Dalam Perkembangan Ilmu Hukum di Indonesia, Soumatera Law Review, Volume 1, Nomor 1, 201. http://doi.org/10.22216/soumlaw.v1i1.3346.

Laurensius Arliman S, Peran Badan Permusyawaratan Desa di Dalam Pembangunan Desa dan Pengawasan Keuangan Desa, Padjadjaran Journal of Law, Volume 4, Nomor 3, 2017. https://doi.org/10.15408/jch.v4i2.3433.

Laurensius Arliman S, Penanaman Modal Asing Di Sumatera Barat Berdasarkan UndangUndang Nomor 25 Tahun 2007 Tentang Penanaman Modal, Supremasi Hukum, Volume 1, Nomor 1, 2018. http://dx.doi.org/10.36441/hukum.v1i01.102 .

Laurensius Arliman S, Memperkuat Kearifan Lokal Untuk Menangkal Intoleransi Umat Beragama Di Indonesia, Ensiklopedia of Journal, Volume 1, Nomor 1, 2018, https://doi.org/10.33559/eoj.v1i1.18.

Laurensius Arliman S, Perkawinan Antar Negara Di Indonesia Berdasarkan Hukum Perdata Internasional, Kertha Patrika, Volume 39, Nomor 3, 2017, https://doi.org/10.24843/KP.2017.v39.i03.p03.

Laurensius Arliman S, Partisipasi Masyarakat Di Dalam Pengelolaan Uang Desa Pasca Undang-Undang Nomor 6 Tahun 2014 Tentang Desa, Jurnal Arena Hukum, Volume 12, Nomor 2, 2019, https://doi.org/10.21776/ub.arenahukum.2019.01202.5.

Laurensius Arliman S, Mewujudkan Penegakan Hukum Yang Baik Di Negara Hukum Indonesia, Dialogica Jurnalica, Volume 11, Nomor 1, 2019, https://doi.org/10.28932/di.v11i1.1831.

Laurensius Arliman S, Mediasi Melalui Pendekatan Mufakat Sebagai Lembaga Alternatif Penyelesaian Sengketa Untuk Mendukung Pembangunan Ekonomi Nasional, UIR Law Review, Volume 2, Nomor 2, 2018, https://doi.org/10.25299/uirlrev.2018.vol2(02).1587

Laurensius Arliman S, Peranan Filsafat Hukum Dalam Perlindungan Hak Anak Yang Berkelanjutan Sebagai Bagian Dari Hak Asasi Manusia, Doctrinal, Volume 1, Nomor 2,2016.

Laurensius Arliman S, Ni Putu Eka Dewi, Protection of Children and Women's Rights in Indonesia through International Regulation Ratification, Journal of Innovation, Creativity and Change Volume 15, Nomor 6, 2021.

Laurensius Arliman S, Gagalnya Perlindungan Anak Sebagai Salah Satu Bagian Dari Hak Asasi Manusia Oleh Orang Tua Ditinjau Dari Mazhab Utilitarianisme, Jurnal Yuridis, Volume 3, Nomor 2, 2016, http://dx.doi.org/10.35586/.v3i2.180.

Laurensius Arliman S, Tantangan Pendidikan Kewarganegaraan Pada Revolusi 4.0, Jurnal Ensiklopedia Sosial Review, Volume 2, Nomor 3, 2020.. 